\title{
EFFECT OF BIOTIC AND ABIOTIC AGENTS IN \\ CONTROLLING CUCUMBER LEAF SPOT CAUSED BY Alternaria cucumerina UNDER PROTECTED CULTIVATION
}

\author{
*Atia M.M., ** O.Y. Shalabv and Amna E. Hedia \\ * Agric. And Pl. Path. Dept.. Fac. Agric., Zagazig Univ. \\ ** Agric. Botany Dept., Fac. Agric., Fayoum Univ.
}

\section{ABSTRACT}

Alternaria cucumerina was isolated from blighted or spotted cucumber leaves. Pathogenicity test revealed that A. cucumerina was pathogenic to cotyledons and true leaves of cucumber plants. Matrix $\mathrm{cv}$. gave the lowest infection with $A$. cucumerina, while Beta alpha recorded the highest infection. On the otherhand, A. cucumerina isolated from cucumber plants had ablility to infect other cucubit plants; i.e. melon; watermelon; pumpkins, Smooth Loofah and squash. Both Bacillus spp. and Trichoderma spp. inhibited the growth of A. cucumerina either in vitro or in vivo. Trichoderma sp., T. harzianum, T. viride and different Bacillus spp. (isolated from cucumber leaf surface) and their culture filtrates significantly inhibited the radial growth of $A$. cucumerina on PDA medium. Various concentrations of some plant oils and plant extracts reduced the radial growth and spore germination of A. cucumerina, especially clove oil. Also, Dithane M-45 was effective in reducing the radial growth of A. cucumerina. Bacillus spp. (isolate 4), T. harzianum, clove oil and Dithane M-45 were the most effective treatments in controlling cucumber leaf spot.

Keywords: Alternaria cucumerina, cucumber, biocontrol, plant extract, plant oils and dithane M-45.

\section{INTRODUCTION}

Alternaria leaf spot, incited by Alternaria cucumerina is an important foliar disease of cucrbits (Thomas, 1990; Latin, 1992 and Atia, 2005 b). Alternaria leaf spot is a perennial problem that must be controlled through the application of protective fungicides, for the presence of primary inoculum from previous crop (Thomas, 1990). Latiny (1992) mentioned that, A. cucumerina, infects plant leaves, fruits and reduce cucumber yield (Parasada et al., 1972). Alternaria leaf spot disease has a wide host range including Cucurbitaceae family, i.e., watermelons, muskmelons, pumpkins, and cantaloupes (Thomas et al., 1990; Latin, 1992 and Atia, 2005 b). Chemical control is a fast and effective method of controlling the fungal diseases (Meena et al., 2004). On the other hand, biological control of Alternaria leaf blight is considered much safer, for health and environmental considerations (Atia, 2005 a,b; Atia and Esh, 2005 and Atia and Ahmed, Amal, 2001). Trichoderma species have long been recognized as agents for the control of numerous plant diseases and for their ability to increase the plant growth and its development (Harman, 2000, Atia, 2005 a and Atia and Ahmed, Amal 2011).Conidia of T. harzianum at a concentration of $2.0 \times 10^{8}$ conidia/ml significantly suppressed the leaf spot on treated cucumber leaf-discs (Batta, 2005). Bacillus strains are examples of promising safe fungal biological control agents. $B$. subtilis, and $B$. licheniformis, showed antifungal activities against Alternaria spp. and other pathogenic fungi in vitro and in vivo (Aly et al, 2002, and Atia and Ahmed, Amal, 2011, Atia et al., 2011, Esh et al., 2010). Plant extract are a new

Fayoum J. Agric. Res. \& Dev., Vol. 26, No.2, July, 2012 
Atia M.M., et al.,

approache for controlling plant diseases. It can be used without any dangerous effects on human healthy (Fawzi et al., 2009 and Atia and Amal Ahmed 2011). Chemical control still the faster factor can be used as a curative or preventive of disease control, but not safety for the human race in most cases. Thus, the use of chemical are restricted and apply them when there are great need. Several fungicides have been used to control alternaria disease i.e Amistar Both Dithane M-45 (mancozeb) and Rovral iprodione + carbendazim (Mesta et al., 2009). The present study was designed to isolate, identify the causal of cucumber alternaria leaf spot, investigate the reaction of cucumber cvs., and cucurbit species as host range, effect of anti-fungal of bio-control agents, plant extract and oils as well as fungicides on the radial growth of $A$. cucumerina and its infection.

\section{MATERIALS AND METHODS Cucumber Plant:}

Cucumber seedlings (cv. Matrix) were cultivated under greenhouse in pots $(12 \mathrm{~cm}$ in diameter) filled with sand/peat mixture $(1: 3 \mathrm{v} / \mathrm{v})$. The plants were fertilized weekly with nutrient solution (according to Atia, 2005 b). Seedlings at the cotyledon stage or 2-3 true leaves were used in this investigation.

\section{Isolation, maintenance and inoculum preparation:}

A. cucumerina, was isolated on potato dextrose agar (PDA) from infected cucumber leaves exhibited typical alternaria leaf spot or leaf blight symptoms and identified according to Jakson (1958); and Barnett (1998). Identification was carried out at Pl. Path. Laboratory, Agric. Bot. and Pl. Path. Dept., Fac. Agric., Zagazig Univ. Fungal isolates were kept under $4^{\circ} \mathrm{C}$ for the further studies. Inoculum of A. cucumerina was prepared from 7-12 day-old culture grown on PDA in Petri dishes using the technique described by Atia, (2005 b). Conidial suspension was adjusted to $5 \times 10^{4}$ spores $/ \mathrm{ml}$ (Latin et al., 1994).

\section{Source of bioagents:}

Bacteria spp. were isolated from leaf surface of cucumber using NA medium. The isolated bacteria were purified using dilution method and were identified according to their shape, pigmentation and culture characteristics based on Bergey's Manual of Determinative Bacteriology $9^{\text {th }}$ ed. (Holt et al., 1994). Trichoderma spp., were obtained from Pl. Path. Laboratory, Agric. Bot. and Pl. Path. Dept., Fac. Agric., Zagazig Univ.

\section{Pathogenicity tests:}

Cucumber cotyledon and true leaves were detached and transferred to moist filter papers inside Petri dishes $(15-\mathrm{cm}$ diameter) withen wet filter paper. Each leaf was inoculated with 4 droplets, each $50 \mu 1$ of $A$. cucumerina spore suspension $\left(5 \times 10^{4}\right.$ spore $\left./ \mathrm{ml}\right)$. The inoculated cotyledons were incubated at $25^{\circ} \mathrm{C}$ for $18 \mathrm{~h}$., then, incubated under fluorescent light with an $11 \mathrm{~h}$. photoperiod. The inoculated true leaves were incubated at $27^{\circ} \mathrm{C}$ for $18 \mathrm{~h}$, then incubated under fluorescent light for $11 \mathrm{~h}$ photoperiod. Number of lesions, lesion diameter, lesion types and blighted area were recorded (Atia, 2005 b).

Susceptibility of cucumber cultivars to infect with A. cucumerina:

Three cultivars of parthenocarpic cucumber i.e. Matrix F1, Best F1 and Beita Alpha were infested with spore suspension $\left(5 \times 10^{4}\right.$ spores $/ \mathrm{ml}$ ) of $A$. cucumerina and incubated at $27^{\circ} \mathrm{C}$., number of lesions; lesion diameter; and lesion type of blighted area were recorded.

Host range tests:

Fayoum J. Agric. Res. \& Dev., Vol. 26, No.2, July, 2012 
EFFECT OF BIOTIC AND ABIOTIC AGENTS IN CONTROLLING.... 62

Six species of cucumbitaceae species i.e. Cantaloupe, Smooth Loofah, Muskmelon, Pumpkin, Squash and Watermelon were cultivated under greenhouse conditions. Inoculation with A. cucumerina, incubation and results were done as aforementioned in pathogenicity test.

\section{In vitro studies}

Effect of selected bio-agents on the radial growth of $\boldsymbol{A}$. cucumerina.

Isolates of Bacillus spp. were grown on nutrient agar while, isolates of

Trichoderma harzianum, T. viride and $T$. spp. isolates were grown on PDA medium.The interaction between aforementioned microorganisms and $A$. cucumerina was tested. Petri dishes ( $9 \mathrm{~cm}$ in diam.) containing PDA medium were inoculated in the centre with disk ( $5 \mathrm{~mm}$ in diam.) taken from the edges of 7 day-old culture of $A$. cucumerina. Inoculation with the tested bacteria isolates was done by streaking on the surface of the media at the distance of $1.5 \mathrm{~cm}$ from the edge of the plates with aid of dual culture method. Discs $(5 \mathrm{~mm}$ in diam.) of Trichoderma isolates were inoculated at the distance of $1.5 \mathrm{~cm}$ from the edge of the plates. Plates inoculated with A. cucumerina alone were used as a control. Three plates were used for each treatment. Radial growth of the different treatments was measured when one plate was full of the growth of $A$. cucumerina. The percentage of the radial growth inhibition of the tested fungus was calculated using the following formula (Atia and Esh, 2005):

Where,

$$
\text { Inhibition } \%=\frac{X-Y}{X} \times 100
$$

$\mathrm{X}=$ Average of the radial growth of the control (A. cucumerina alone) plate $(\mathrm{cm})$.

$\mathrm{Y}=$ Average of the radial growth of the treated plate $(\mathrm{cm})$.

\section{Effect of bioagents culture filtrates on the radial growth of Alternaria cucumerina:}

Isolates 1 and 4 of of Bacillus spp. were grown in nutrient broth medium at $28{ }^{\circ} \mathrm{C}$ for $36 \mathrm{~h}$. Trichoderma isolates were grown on PD browth, at $28{ }^{\circ} \mathrm{C}$ for 7-10 days (Aly et al., 2002). Cultures of Bacillus isolates were collected, filtered through filter papers, centrifuged at $3000 \mathrm{rpm}$ for 15 minutes and sterilized using bacterial filter (filter syringe, $0.45 \mu \mathrm{m}$ followed by $0.25 \mu \mathrm{m}$ using Seitz apparatus) (Aly et al., 2002). Culture filterate of Trichoderma spp. was filtered through filter paper and sterilized by using Seitz apparatus. The sterilized culture filtrates were added to flasks contained PDA medium before solidification at the rate of 5, 10 and $15 \%$ of the medium and poured in Petridishes. Bioagents-free plates were used as control. All plates (3 plates /each treatment) were inoculated with an equal disc $(5 \mathrm{~mm}$ in diameter) from the edges of 7 day-old $A$. cucumerina culture at the centre of each plate and incubated at $28^{\circ} \mathrm{C}$ until one plate was full of A. cucumerina growth. Results were recorded as aforementioned.

\section{Effect of some plant oils on the radial growth of $\boldsymbol{A}$. cucumerina:}

Oils of ten plants, i.e. marjoram (Majorana hortensis), thyme (Thymus vulgaris L.), clove (Syzygium aromaticum), onion (Allium cepa), garlic (Allium sativum L.), olibanum (Baswellia scacra), cress (Eruca sativa Mill.), basil (Ocimum basilicum), cinnamon (Cinnamomum zeylanicum) and ginger (Zingiber officinale), were obtained from El-Captain Company, Egypt were used in this study. Four concentrations; i.e. $0 ; 0.5 ; 0.1 ;$ and $2 \%$ of aforementioned plant oils were individually prepared by dissolving in $100 \mathrm{ml}$ of autoclaved PDA before soildifing using $0.1 \mathrm{ml}$ of tween 20 . Oils were

Fayoum J. Agric. Res. \& Dev., Vol. 26, No.2, July, 2012 
Atia M.M., et al.,

individually mixed with media and poured in Petri dish $(9 \mathrm{~cm}$ in diam.). After solidification, plates were inoculated with A. cucumerina. Four replicates were used for each concentration. Oil- free PDA plates were used as a control. The inoculated plates were incubated at $28 \pm 2{ }^{\circ} \mathrm{C}$. Data were recorded after 7 days as aforementioned.

Effect of some plant extracts using cold and boiled distilled water on the radial growth of Alternaria cucumerina:

Three medicinal plants i.e. clove, basil and marjoram were dried, ground to fine powder. Ten gms powder was extracted by macerating in $100 \mathrm{ml}$ of either sterilized cold distilled water (CDW) for $24 \mathrm{hr}$, or boiled distilled water (BDW) for $10 \mathrm{~min}$. in water bath at $100{ }^{\circ} \mathrm{C}$. The extracts were filtered through filter paper, and sterilized through bacterial filter (filter syringe; $0.45 \mu \mathrm{m}$ followed with $0.25 \mu \mathrm{m}$ using Seitz apparatus). Three replicates of 4 concens; i.e. $0,5,10$, and $15 \%$ were prepared from crude extract (100\%) and were added to $100 \mathrm{ml}$ of PDA medium before solidifying. Extracts-free medium was served as a control. Inoculation and incubation were done as aforementioned.

Effect of some fungicides on the radial growth of $\boldsymbol{A}$. cucumerina:

Six concentrations; i.e. 0, 125, 250, 500, 1000, and $2000 \mathrm{ppm}$ of 4 fungicides; i.e. Dithane M-45, Zineb, Ridomel and Topsin-M were tested to evaluate their effect on the radial growth of $A$. cucumerina using poison medium technique (Atia, 2005 b). Four replicates of A. cucumerina were used for each particular concentration. Inoculation, incubation and growth reduction were carried out as aforementioned.

Effect of some plant oils and Dithane-M 45 on the spore germination of $A$. cucumerina:

Three concentrations; i.e. $0,0.5$, and $2 \%$ of oils of 3 plants; i.e. basil, marjoram, clove as well as 4 concentrations; i.e. 0, 2000, 2500, and $3000 \mathrm{ppm}$ of Dithane were individually added to $250 \mathrm{ml}$ PDA before solidification and poured in Petri dishes.The plates were individually inoculated with $2 \mathrm{ml}$ of spore suspension $\left(5 \times 10^{4}\right.$ spore/ $\left.\mathrm{ml}\right)$ of A. cucumerina and spread with sterilized glass rod on the surface of the plates. Three replicates were used for each tested concentration. Oils or fungicide free plates were used as a control. All treatments were incubated at $28{ }^{\circ} \mathrm{C} \pm 2$. After 15 to $18 \mathrm{hr}$ the germinated and non-germinated spores were counted in ten microscopic fields chosen at random for each slide (Sharvelle,1961). The percentage of spores germination was calculated.

\section{In vivo studies}

Effect of selected bioagents on cucumber leaf spot disease.

The most effective bioagents; i.e. Bacillus spp. and Trichoderma spp. on reducing radial A. cucumerium were used. Fungal isolates (Trichoderma spp) were grown on $200 \mathrm{ml}$ of sterilized PD broth in $500 \mathrm{ml}$ Erlenmeyer flasks on a rotary shaker (100 rpm) for 7 days at $28{ }^{\circ} \mathrm{C} \pm 2$ (Aly et al., 2002). The liquid culture were mixed in a blender and adjusted to contain $10^{6} \mathrm{cfu} / \mathrm{ml}$. Bacillus isolates were grown on NB (Atia and Ahmed Amal, 2011). Flasks (500 ml) each containing $100 \mathrm{ml}$ of NB medium were inoculated with a lop full of $24 \mathrm{~h}$ old of Bacillus cultures. Flasks were incubated at $28{ }^{\circ} \mathrm{C} \pm 2$ on rotary shaker (100 rpm) for $24 \mathrm{~h}$ in case of bacterial bioagents (Aly et al., 2002). Cucumber plants Matrix cv. (45 day-old) were individually sprayed with $30 \mathrm{ml} /$ plant of each tested organism. Control treatment were sprayed with water. The treated plants were left for two hours and then individually inoculated with $A$. cucumerina (4 drops , $20 \mu \mathrm{l}$ of $10^{5} \mathrm{cfu} / \mathrm{leaf}$ ) and covered with plastic socks and

Fayoum J. Agric. Res. \& Dev., Vol. 26, No.2, July, 2012 
EFFECT OF BIOTIC AND ABIOTIC AGENTS IN CONTROLLING.... 64

kept under greenhouse conditions. In addition, detached leaves of cucumber were inoculated with 4 droplets $(20 \mu \mathrm{l})$ of a mixture of tested the bio-agents (Bacillus spp. cell and Trichoderma spp. spores) and A. cucumerina spore suspension $(1: 1 \mathrm{v} / \mathrm{v})$. Detached leaves were transferred into moist Petri dishes. Inoculum-free plates were used as a control. Three Petri-dishes $(15 \mathrm{~cm}$ in diam.) were used as replicates for each treatment. Plates were incubated at $28{ }^{\circ} \mathrm{C} \pm 2$ and the disease incidence was calculated after 7-10 days. Number and diameter of necrotic lesions $(\mathrm{mm})$ as well as blighted area $\left(\mathrm{mm}^{2}\right) /$ leave were determined. Percentage of protection was calculated as follows (Aly et al., 2002):

Where:

Percentage of protection $=100-\mathrm{A} / \mathrm{B}$

$\mathrm{A}=$ Percentage of disease in treated (100 blighted area in treated/

blighted area in the untreated (control).

$\mathrm{B}=$ percentage of disease in untreated (control).

Effect of clove oil and Dithane-M45 on cucumber leaf spot disease:

Cucumber plants were treated with Dithane-M45 at the rate of $0.2 \%$ (2 $\mathrm{g} / \mathrm{l})$ or clove oil at the rate of $0.5 \%(5 \mathrm{ml} / \mathrm{l})$ untill run off and left till plant were dryied. Treated leaves were transferred into moist filter papers in Petri dishes (15 cm in diam.) and inoculated with A. cucumerina spore suspension as mentioned before. Inoculum free plates were used as a control. Three Petridishes were used for each treatment. Incubation and results were recorded as mentioned above.

Statistical Analysis:

All of the obtained data were subjected to statistical analysis (Snedecor and Cochran, 1980) using SAS (SAS, 1999).

\section{RESULTS AND DISCUSSION}

Isolation and pathoginicity:

The isolated fungus, A. cucumerina seem to be the main causal organism of cucumber alternaria leaf blight. Isolation was carried out with PDA medium (Latin et al., 1994). The isolated fungus was identified as $A$. cucumerina (Ellis and Everh J. A. Elliott). Identification was carried out according to disease symptoms, morphological characteristics of mycelia, hyphal conidia (Latin et al., 1994 and Barnett, 1998).

Results in Table (1) indicate that, A. cucumerina was pathogenic to cucumber cotyledon and true leaves. It also clear that, inoculation of cotyledons resulted in high significant of both lesion diameter $(4.66 \mathrm{~cm}$.) and blighted area $\left(68.2 \mathrm{~cm}^{2}\right)$ than of the true leaves $\left(6.42 \mathrm{~cm}^{2}\right)$, lesion size/leaf and blighted for both respectively) after nine days of inoculation. Moreover, 9 days lesion size was expanded on cotyledon leaves more than on the true leaves. Lesions on cotyledon leaves were surrounded by a wide yellow margin, while it was narrow in the case of the true leaves. Simillar results on melon were obtained (Atia, 2005 b). Respecting the increases of infection with A. cucumerina on cotyledon leaves may be due to the low of sugars percentage on these leaves (Atia, 2005 b).

The fungi caused a cellular leakage and reduced chlorophyll content in susceptible cultivars (Alabouvette et al., 1984). In addition, necrotrophs i.e. Alternaria kills host cells prior to colonization, and that toxins are secreted to facilitate host cell death (Lawrence et al., 2008.

Fayoum J. Agric. Res. \& Dev., Vol. 26, No.2, July, 2012 
Atia M.M., et al.,

Table (1): Pathogenicity test of Alternaria cucumerina on cucumber cv. Matrix on cotyledon and true leaves.

\begin{tabular}{lccc}
\hline \multirow{2}{*}{ Type of leaves } & \multicolumn{3}{c}{ Disease parameters (9 days after inoculation) } \\
\cline { 2 - 4 } & $\begin{array}{c}\text { Average of } \\
\text { lesions/leaf }\end{array}$ & $\begin{array}{c}\text { Average of } \\
\text { lesion }(\mathbf{c m})\end{array}$ & $\begin{array}{c}\text { Blighted } \\
\text { area }\left(\mathbf{c m}^{\mathbf{2}}\right)\end{array}$ \\
\hline Cotyledon leaves & 4 & 4.66 & 68.20 \\
True leaves & 4 & 1.43 & 6.42 \\
\hline LSD (0.05) & N.s. & 0.47 & 24.41 \\
\multicolumn{1}{c}{ N.S. = Non significant } & &
\end{tabular}

Susceptibility test of cucumber cultivars with A. cucumerina.

Results in Table (2) indicate that Matrix cv. gave the lowest infection with A. cucumerina (3 lesions / leaf ; $1.27 \mathrm{~cm}$ diameter of lesion ; and $3.8 \mathrm{~cm}^{2}$ blighted area). While, Beta alpha was the highest infecion $(3.02 \mathrm{~cm}$ diameter of lesion/leaf and $21.48 \mathrm{~cm}^{2}$ blighted area), nine days after inoculation. After 9 days, lesion size was expanded. Lesions were recorded a circular, light brown with a narrow yellow margin. There were significant differences between the diameter of lesion and infected area of the tested cvs. of cucumber.

Table (2): Susceptibility of the tested cucumber cultivars to Alternaria cucumerina.

\begin{tabular}{|c|c|c|c|}
\hline \multirow[b]{2}{*}{ Cultivars } & \multicolumn{3}{|c|}{$\begin{array}{c}\text { Disease parameters (nine days after inoculation on true } \\
\text { leaves) }\end{array}$} \\
\hline & $\begin{array}{l}\text { Average of } \\
\text { lesion/ leaf }\end{array}$ & $\begin{array}{r}\text { Average } \\
\text { diam. of } \\
\text { lesion }(\mathbf{c m})\end{array}$ & Blighted area $\left(\mathrm{cm}^{2}\right)$ \\
\hline Matrix & 3 & 1.27 & 3.80 \\
\hline Best & 3 & 2.85 & 19.13 \\
\hline $\begin{array}{l}\text { Beta } \\
\text { alpha }\end{array}$ & 3 & 3.02 & 21.48 \\
\hline LSD (0.05) & N.s. & 0.68 & 2.33 \\
\hline
\end{tabular}

N.s. = Non significant

Host range tests:

A. cucumerina isolated was able to infect melon, cucumber, watermelon, pumpkin, zucchini and Smooth Loofah. Squash gave the highest infection followed by pumpkins $(6.04$ and $5.21 \mathrm{~cm}$ diameter of lesion/leaf, as well as 85.91 and $63.92 \mathrm{~cm}^{2}$ blighted area, respectively) ten days after inoculation. While, muskmelon was the lowest infected host followed by watermelon (1.44 and $2.80 \mathrm{~cm}$ diameter of lesion/leaf and $4.8818 .46 \mathrm{~cm}^{2}$ blighted area) (Table, 3 and Fig.1). Lesions were circular, light brown to black in colour with variation a wide yellow margin. The differences between the diameter of lesion and infected area of the host plants were significantly with some extent. The filtrates of pathogenic fungi containing their respective toxins, which caused a necrosis within $48 \mathrm{hrs}$ and eventually mortality on susceptible cultivars.Many phytopathologist previously mentioned similar results. Vakalounakis, (1990) reported that, 27 species of Cucurbitaceae were found to be susceptible to infect with $A$. alternata artificially inoculated or exposed to natural infection in the greenhouse. Also A. cucumerina was known to infect different genotypes of melon i.e. muskmelon (Latin, 1992).

Fayoum J. Agric. Res. \& Dev., Vol. 26, No.2, July, 2012 
EFFECT OF BIOTIC AND ABIOTIC AGENTS IN CONTROLLING.... 66 Table (3): Reaction of different cucurbit plants to Alternaria cucumerina.

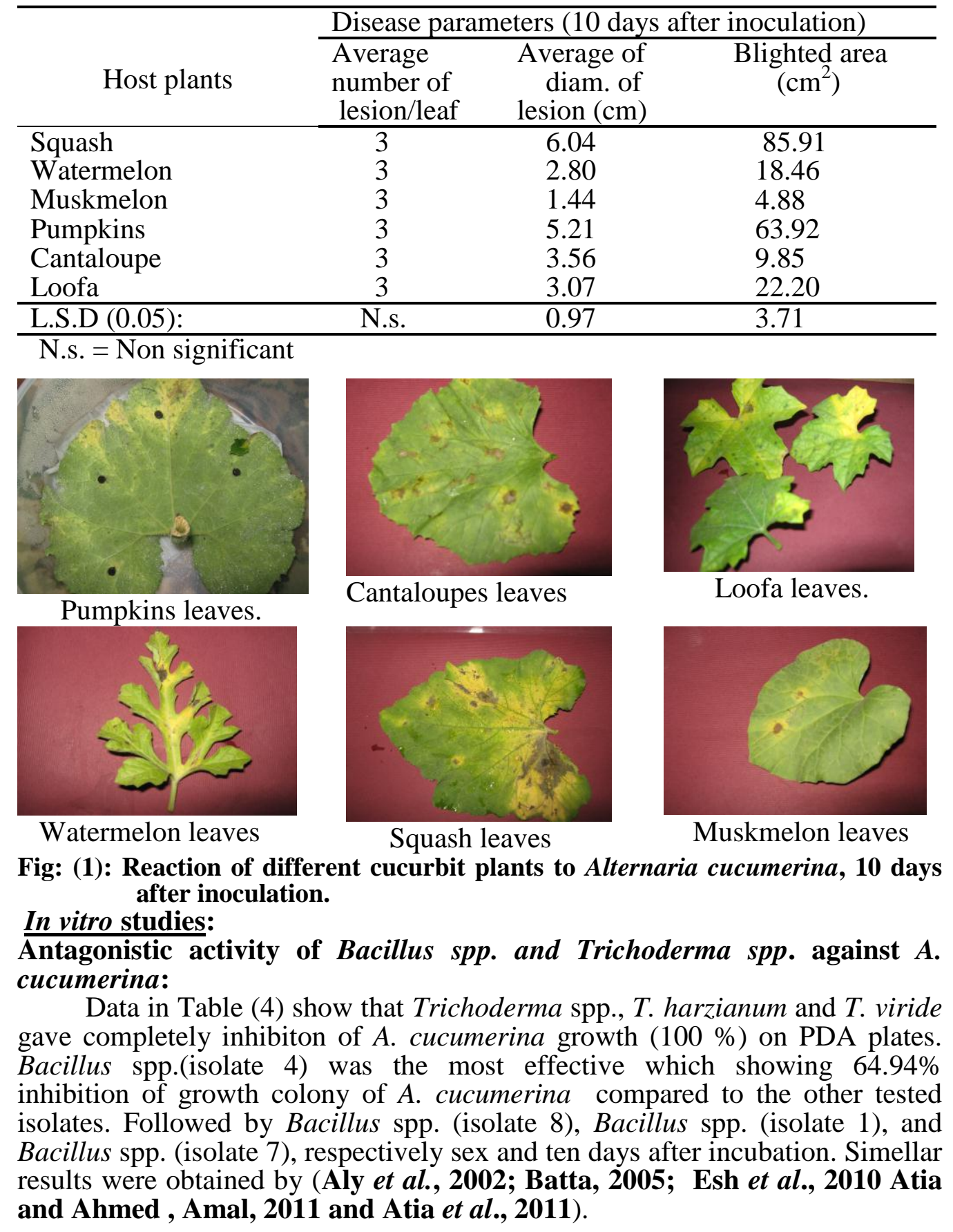

Fayoum J. Agric. Res. \& Dev., Vol. 26, No.2, July, 2012 
Atia M.M., et al.,

Table (4): The inhibitory effect of the tested bacterial and fungal isolates against Alternaria cucumerina.

\begin{tabular}{lcc}
\hline Bioagent & \% Reduction after \\
\cline { 2 - 3 } & 6 days & 10 days \\
\hline Control & 0.00 & 00.00 \\
Bacillus spp.(I1) & 60.77 & 72.78 \\
B. spp.(I4) & 64.94 & 79.44 \\
B. spp.(I5) & 46.58 & 61.11 \\
B. spp.(I6) & 34.89 & 52.78 \\
B. spp.(I7) & 57.43 & 70.56 \\
B. spp.(I8) & 61.60 & 73.33 \\
T. harzianum & 100.00 & 100.00 \\
T. spp. & 100.00 & 100.00 \\
T. viride & 100.00 & 100.00 \\
\hline Mean & 62.62 & 71.00 \\
\hline L.S.D. (0.05): & 3.18 & 1.42 \\
\hline
\end{tabular}

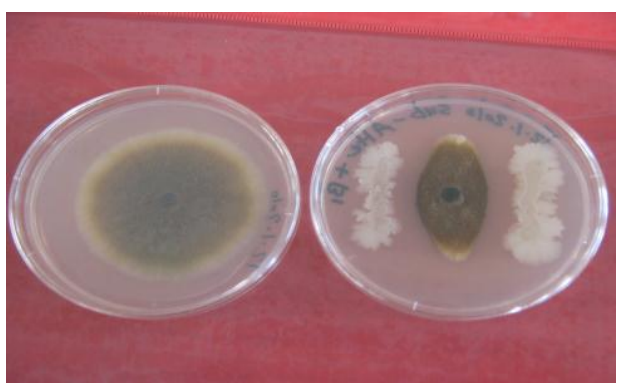

Bacillus spp., (I 1)

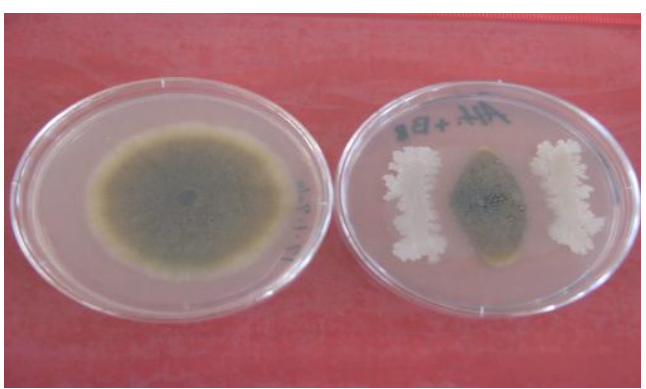

Bacillus spp., (I 4)

Fig. (2): Effect of Bacillus spp. isolates on the mycelial growth of Alternaria cucumerina

Bacillus spp. isolated from phyllosphere was used against several diseases; i.e. late blight of tomato (Aly et al., 2002). Bacilli are known to produce a wide range of antibiotic compounds that are inhibitory to fungi and its capacity to use chitin and $\beta$-glucan as substrates, (Bargabus et al., 2004); potato late blight (Atia, 2005 a); gray mould of strawberries (Ju, et al., 2007); cucurbit powdery mildew (Gilardi, et al., 2008). Several bacterial genera have been successfully used for the biological control of other plant diseases (Chen et al., 2008 and Gilardi et al., 2008); and cercospora leaf spot of sugar beet (Esh et al., 2010).

Trichoderma strains have highly effective antagonistic mechanisms to survive and colonize the competitive organisms of the rhizosphere, phyllosphere and spermosphere. A major part of Trichoderma antifungal system consists of a number of genes encoding for an astonishing variety of secreted lytic enzymes, including endochitinases, $\mathrm{N}$-acetyl- $\beta$-glucosaminidases, chitin $1,4-\beta$-chitobiosidases, proteases, endo- and exoglucan $\beta$-1,3-glucosidases, endoglucan $\beta$-1,6-glucosidases, lipases, xylanases, mannanases, pectinases, pectin lyases, amylases, phospholipases, RNAases, and DNases (Lorito, 1998).

Effect of Bacillus spp. and Trichoderma spp. filtrates on radial growth of A. cucumerina:

Data in Table (5) show that, culture filtrate (at $10 \%$ and $15 \%$ cocentrations) of Bacillus spp. (isolates 1 and 4) inhibited the radial growth of A. cucumerina and the effect increased by increasing the concentration. Culture filtrate of

Fayoum J. Agric. Res. \& Dev., Vol. 26, No.2, July, 2012 
EFFECT OF BIOTIC AND ABIOTIC AGENTS IN CONTROLLING.... 68

Bacillus spp. (isolate 1), was the most effective, followed by Bacillus sp. (4) filtrate. On the otherhand, Trichoderma spp., resulted in the lowest effect (Table 5) and Figure (3). These results are agreement with those obtained by Leifert et al., (1995) who found that, B. polymyxa KB-8 produced at least two antibiotics, KB-8A and $\mathrm{KB}-8 \mathrm{~B}$. However, these antibiotics produced in vitro can not provide a sufficient proof for the involvement of the antibiotics in the biocontrol activity in vivo, because Bacillus spp. produce other metabolites including biosurfactants, chitinase and other fungal cell wall-degrading enzymes, volatiles and compounds which elicit plant resistance mechanisms, and are involved in a number of mechanisms of biological control not only a antibiosis but also competition.

Table (5): Effect of bio-agent culture filtrates on the radial growth of Alternaria cucumerin:

\begin{tabular}{lccccc}
\hline \multirow{2}{*}{ Treatments } & \multicolumn{6}{c}{ \% Culture filtrate concentrations } \\
\cline { 2 - 6 } & \multicolumn{0}{c}{0} & $\mathbf{5}$ & $\mathbf{1 0}$ & $\mathbf{1 5}$ & Mean \\
\cline { 2 - 6 } & Growth reduction (\%) & & \\
\hline B. spp. (I1) & 0 & 88.62 & 100.0 & 100.0 & 96.21 \\
B. spp. (I4) & 0 & 54.11 & 56.9 & 56.13 & 55.71 \\
T. spp. & 0 & 9.72 & 23.09 & 27.34 & 20.05 \\
\hline Mean & & 38.11 & 44.01 & 45.87 & 42.99 \\
\hline
\end{tabular}

L.S.D. (0.05):

Treatments $(\mathrm{T})=0.08$

Concentration (C) 0.08

$\begin{array}{ll}\text { T. X C. } & 0.13\end{array}$

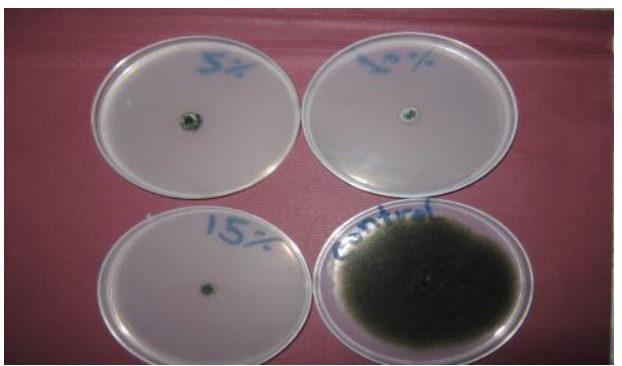

Bacillus spp. (I 1)

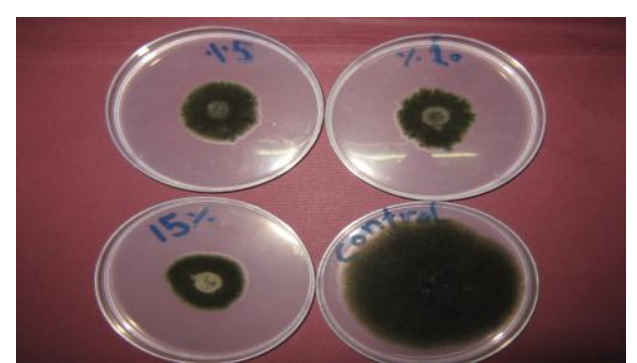

Bacillus spp. (I 4)

Fig. (3): Effect of Bacillus spp. culture filtrates on the growth of Alternaria cucumerina

Effect of some plant oils on the radial growth of Alternaria cucumerina:

Data presented in Table (6) and Figure (4) indicate that clove oil at 4 concens was the most effective on reducing the radial growth of A. cucumerina, followed by the marjoram oil, basil oil cinnamon oil. While, cress oil was not effective, compared to control treatment. The obtained data are in agreement with those obtained by Parajuli et al., (2005); Mironescu and Georgescu, (2008); Sitara et al., (2008); Fawzi et al., (2009) and Atia, and Ahmed, Amal (2011).

Clove oil was the most effective on inhibition growth of A. cucumerina, due to its content of eugenol, the major component of clove oil (Chami et al, 2005). The inhibitory effect of plant oils might be regarded to which act as cidal agent against fungal growth and showed abnormal conidia and malformations as swollen, often septated and pale color of hypha (Suwitchayanon and Kunasakdaku, 2009).

Some of plant oils can inhibit the conidial germination of cucumber and barley powdery mildews. Furthermore, mycelial growth of many pathogens was

Fayoum J. Agric. Res. \& Dev., Vol. 26, No.2, July, 2012 
Atia M.M., et al.,

severely restricted after application of oils. Levels of hydrogen peroxide $\left(\mathrm{H}_{2} \mathrm{O}_{2}\right)$ and superoxide $\left(\mathrm{O}^{2-}\right)$, and some antioxidants were decreased such as dehydroascorbate reductase (DHAR), but the other enzymes were increased such as ascorbate peroxidase and glutathione $S$ transferase (Hafez, 2008).

Table (6): Effect of different concentrations of essential oil on the growth reduction percentage of Alternaria cucumerina.

\begin{tabular}{|c|c|c|c|c|}
\hline Treatments & 0.5 & $\mathbf{1}$ & 2 & Mean \\
\hline & Growth reduction (\%) & & & \\
\hline Clove & 100.00 & 100.00 & 100.00 & 100.0 \\
\hline Marjoram & 57.40 & 84.76 & 85.95 & 76.04 \\
\hline Basil & 38.31 & 41.27 & 78.55 & 52.71 \\
\hline Cinnamon & 19.82 & 38.61 & 63.31 & 40.58 \\
\hline Ginger & $19.8 \overline{2}$ & 22.04 & 38.91 & 26.92 \\
\hline Thyme & 10.06 & 12.72 & 20.86 & 14.55 \\
\hline Onion & 5.77 & 23.08 & 35.32 & 21.39 \\
\hline Garlic & 3.85 & 10.95 & 17.16 & 10.65 \\
\hline Olbanum & 1.18 & 5.33 & 6.51 & 4.34 \\
\hline Cress & -3.25 & -0.59 & -0.59 & -1.48 \\
\hline Control & 0.00 & 0.00 & 0.00 & 0.00 \\
\hline Mean & 22.10 & 30.31 & 40.55 & 31.43 \\
\hline L.S.D (0.05): & & & & \\
\hline Treatments $(\mathrm{T})$ & 0.28 & & & \\
\hline Concentrations (c) & 0.15 & & & \\
\hline T. X C. $=$ & 0.28 & & & \\
\hline
\end{tabular}

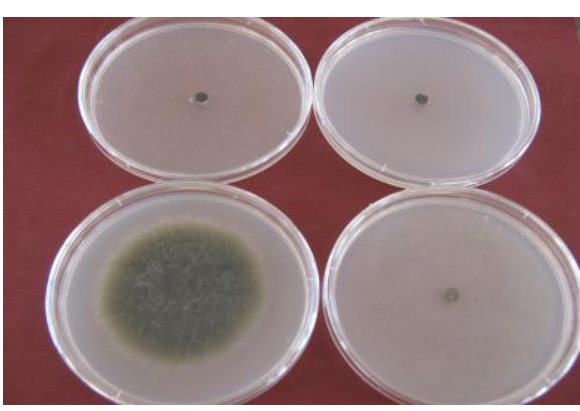

Clove oil

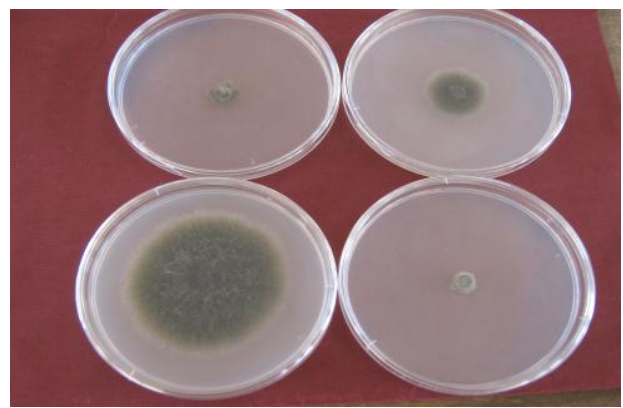

Marjoram oil

Fig. (4): Effect of different plant oils on the mycelial growth reduction of Alternaria cucumerina.

Effect of some plant extracts on the radial growth of Alternaria cucumerina

Data in Table (7) show that, clove extract at all concentrations tested was the most effective in reducing the radial growth of $A$. cucumerina followed by marjoram. On the otherhand basil was not effective as a boiling and cold distilled water. Significantly differences were detected between the tested plant extracts. These results are agree with those found by Fawzi et al., (2009) and Suwitchayanon and Kunasakdakul, (2009).

Effect of some fungicide on the radial growth of A. cucumerina:

Dithane M-45 was the most effective on reducing the radial growth of $A$. cucumerina, followed by Topsin-M then Zineb. The inhibition effect was increased with increasing the concentrations. While, Ridomil recorded the lowest effect (Table, 8). The results of some researchers were agreement with our results (Atia and Ahmed, Amal 2011).

Fayoum J. Agric. Res. \& Dev., Vol. 26, No.2, July, 2012 
EFFECT OF BIOTIC AND ABIOTIC AGENTS IN CONTROLLING.... 70

Table (7): Effect of different concentrations of some plant extracts using cold distilled water (CDW) and boiled distilled water (BDW) on the radial growth reduction of Altrenaria cucumerina:

\begin{tabular}{|c|c|c|c|c|c|c|c|c|}
\hline \multirow{4}{*}{ Treatments } & \multicolumn{8}{|c|}{ \% Growth reduction of Alternaria cucumerina } \\
\hline & \multicolumn{4}{|c|}{ Boiled distilled water } & \multicolumn{4}{|c|}{ Cold distilled water } \\
\hline & \multicolumn{8}{|c|}{ Plant extracts concentrations (\%) } \\
\hline & 5 & 10 & 15 & Mean & 5 & 10 & 15 & Mean \\
\hline Clove & 15.43 & 47.77 & 64.09 & 42.43 & 11.55 & 38.55 & 56.61 & 35.57 \\
\hline Marjoram & -0.59 & 6.53 & 15.13 & 7.02 & 8.38 & 10.99 & 14.34 & 11.24 \\
\hline Basil & -9.50 & -6.38 & -6.03 & -7.30 & -8.38 & 3.72 & 11.92 & 2.42 \\
\hline Control & 0.00 & 0.00 & 0.00 & 0.00 & 0.00 & 0.00 & 0.00 & 0.00 \\
\hline \multicolumn{8}{|c|}{ L.S.D. (0.05): } & 2.31 \\
\hline \multicolumn{2}{|c|}{ Treatments $(\mathrm{T})$} & 0.06 & & & & & & \\
\hline \multicolumn{2}{|c|}{ Concentrations (C) } & 0.07 & & & & & & \\
\hline \multicolumn{2}{|l|}{ T. X C. } & 0.12 & & & & & & \\
\hline
\end{tabular}

Table (8): Effect of different fungicides on the radial growth reduction of A. cucumerina.

\begin{tabular}{|l|l|c|c|c|c|c|}
\hline \multirow{2}{*}{ Fungicides } & \multicolumn{6}{|c|}{ \% Growth reduction at concentrations (ppm) } \\
\cline { 2 - 7 } & $\mathbf{0}$ & 125 & 250 & 500 & 1000 & 2000 \\
\hline DithaneM- 45 & 0 & 77.21 & 82.76 & 85.47 & 100.00 & 100.00 \\
Topsin-M & 0 & 18.23 & 20.51 & 25.21 & 30.20 & 36.61 \\
Zineb & 0 & -13.68 & -9.69 & -3.56 & 3.56 & 10.54 \\
Ridomil & 0 & -17.09 & -16.10 & -14.39 & -13.96 & -11.25 \\
\hline Mean & 0 & 12.93 & 15.50 & 18.69 & 23.96 & 27.18 \\
\hline
\end{tabular}

Ridomil was noted as ineffective against of A. cucumerina (Sitara et al., 2008). Results (Table 8) indicated that, the tested fungicides were significantly differed in their action against the fungi. Differences in reaction might be due to selective action of the fungicide fungus (Singh and Siradhana, 1990).

Effect of oils and fungicides on the spore germination of A. cucumerina:

Dithane M-45 being the most effective in reducing spore germination of A. cucumerina at all concentrations, followed by clove oil and basil. While marjoram was the lowest effective (Table, 9). These results are in agreement with those reported by Hafez, (2008) and Mesta et al., (2009).

Table (9): Effect of some plant oils and Dithane-M 45 on the percentage of spore germination of $A$. cucumerina

\begin{tabular}{|c|c|c|c|c|c|c|c|c|c|c|}
\hline \multicolumn{11}{|c|}{ Treatments } \\
\hline \multicolumn{8}{|c|}{ Plant oils } & \multirow{2}{*}{\multicolumn{3}{|c|}{$\begin{array}{c}\text { Fungicides } \\
\begin{array}{c}\text { DithaneM-45 } \\
\text { (ppm) }\end{array}\end{array}$}} \\
\hline $\begin{array}{r}\text { Cor } \\
(\mathrm{n}\end{array}$ & & $\mathrm{Clo}_{(\mathrm{r}}$ & $\begin{array}{l}\text { e oil } \\
\text { /l) }\end{array}$ & $\begin{array}{l}\mathrm{Ma} \\
\text { oil }\end{array}$ & $\begin{array}{l}\text { oram } \\
\mathrm{n} / \mathrm{l})\end{array}$ & $\begin{array}{r}\mathrm{Bas} \\
(\mathrm{n}\end{array}$ & $\begin{array}{l}\text { 1 oil } \\
\text { /1) }\end{array}$ & & & \\
\hline 0.5 & 2 & 0.5 & 2 & 0.5 & 2 & 0.5 & 2 & 0 & 1000 & 2000 \\
\hline 0 & 0 & 12.57 & 35.43 & 7.79 & 9.95 & 11.47 & 34.12 & 0 & 0 & 0 \\
\hline
\end{tabular}

In vivo studies:

Diseases management with plant oil and DithaneM-45:

Results in Table (10) and Figure (5) indicate that, Dithane M-45 and clove oil significantly reduced cucumber leaf spot compared to untreated control at nine days after inoculation. The present results are in agreement with those reported by (Batta, 2003 and Hafez, 2008). Although in vitro screening

Fayoum J. Agric. Res. \& Dev., Vol. 26, No.2, July, 2012 
Atia M.M., et al.,

of plant extracts is an important of first step in identifying plants with potential application in agriculture, in vivo confirmation of this potential is essential in the search for plant derived preparations with the potential to be commercialized (Tegegne and Pretorius, 2007). The inhibitory effects of plant oils might be regarded to which act as cidal agent against fungal growth and showed abnormal conidia and malformations as swollen, often septated and pale color of hypha (Suwitchayanon and Kunasakdaku, 2009).

Table (10): Effect of clove oil and DithaneM-45 against alternaria leaf spot caused by Alternaria cucumerina of cucumber Matrix cv. 9 days after inoculation.

\begin{tabular}{llllll}
\hline \multirow{2}{*}{ Treatments } & \multicolumn{5}{c}{ Disease parameters } \\
\cline { 2 - 6 } & $\begin{array}{l}\text { Number } \\
\text { of lesion }\end{array}$ & $\begin{array}{l}\text { Diameter } \\
\text { of lesion } \\
(\mathbf{c m})\end{array}$ & $\begin{array}{l}\text { Blighted } \\
\text { area } \\
\left.\mathbf{( c m}^{2}\right)\end{array}$ & $\begin{array}{l}\text { Blighted } \\
\text { area }(\%)\end{array}$ & $\begin{array}{l}\text { Protecti } \\
\text { on (\%) }\end{array}$ \\
\cline { 2 - 6 } DithaneM-45 & 4 & 0.00 & 0.00 & 0.00 & 100.00 \\
Clove oil & 4 & 0.00 & 0.00 & 0.00 & 100.00 \\
\hline Control & 4 & 2.91 & 26.60 & 100.00 & 0.00 \\
\hline
\end{tabular}

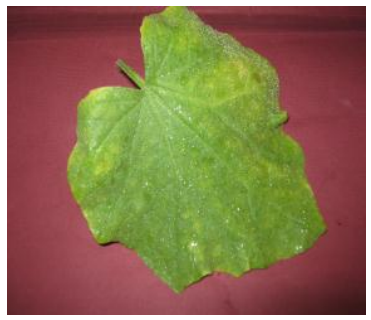

Clove oil

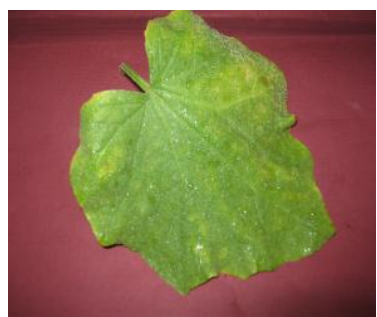

DithaneM-45

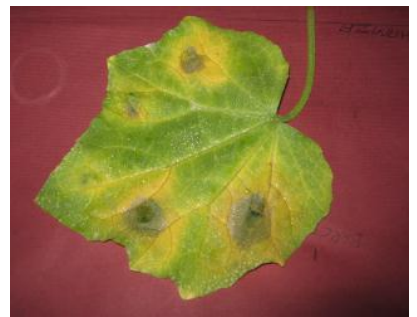

Control

Figs. (5): Effect of DithaneM-45 and clove oil on cucumber leaf spot caused by Alternaria cucumerina:

\section{Diseases management with bioagents (T. harzianum and Bacillus spp ):}

Results in Table (11) and Figure (6) indicate that, cucumber plants treated with Bacillus spp. (isolate 4) as spray and as a mixture application effectivelly reduced lesion diameter $(0.87$ and $0.77 \mathrm{~mm})$ and blighted area $(2.38$ and $1.86 \mathrm{~mm}^{2}$ ), followed by $T$. harzianum $(2.07$ and $2.69 \mathrm{~mm}$ of lesion diameter) and blighted area (13.46 and $\left.22.72 \mathrm{~mm}^{2}\right)$. While, control one recorded $4.66 \mathrm{~cm}$ and $68.19 \mathrm{~mm}^{2}$. Similar results were obtained by Aly et al., (2002), Esh et al., (2010) and Atia and Ahmed Amal (2011). 
EFFECT OF BIOTIC AND ABIOTIC AGENTS IN CONTROLLING.... 72 Table (11): Effect of bacterial and fungal bioagents isolates against alternaria leaf spot caused by Alternaria cucumerina of cucumber cv. Matrix- 9 days after inoculation.

\begin{tabular}{|c|c|c|c|c|c|}
\hline \multirow[t]{2}{*}{ Treatments } & \multicolumn{5}{|c|}{ Disease parameters } \\
\hline & $\begin{array}{l}\text { Number } \\
\text { of lesion }\end{array}$ & $\begin{array}{l}\text { Diameter of } \\
\text { lesion }(\mathrm{cm})\end{array}$ & $\begin{array}{r}\text { Blighted } \\
\text { area }\left(\mathrm{cm}^{2}\right)\end{array}$ & \begin{tabular}{|c|}
\multicolumn{2}{|c|}{ Blighted } \\
area $(\%)$ \\
\end{tabular} & $\begin{array}{c}\text { Protection } \\
(\%) \\
\end{array}$ \\
\hline $\begin{array}{l}\text { Bacillus spp. (4) spray } \\
\text { application }\end{array}$ & 4 & 0.87 & 2.38 & 3.49 & 96.51 \\
\hline $\begin{array}{c}\text { Bacillus spp. (4) mixture } \\
\text { inoculation }\end{array}$ & 4 & 0.77 & 1.86 & 2.73 & 97.27 \\
\hline T.harzianum application & 4 & 2.07 & 13.46 & 19.74 & 80.26 \\
\hline $\begin{array}{c}\text { T.harzianum mixture } \\
\text { inoculation }\end{array}$ & 4 & 2.69 & 22.72 & 33.32 & 66.68 \\
\hline Control & 4 & 4.66 & 68.19 & 100 & $\mathbf{0 . 0 0}$ \\
\hline L.S.D. (0.05): & & 1.10 & 0.50 & & \\
\hline
\end{tabular}

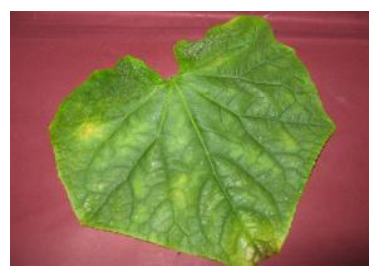

Bacillus spp.

(I 4) spray

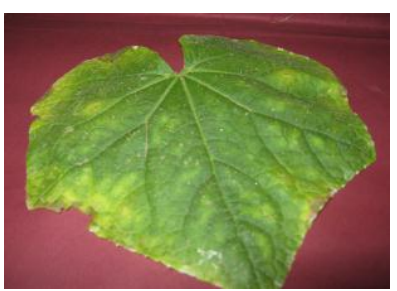

Bacillus spp. (I 4) mixture inoculation

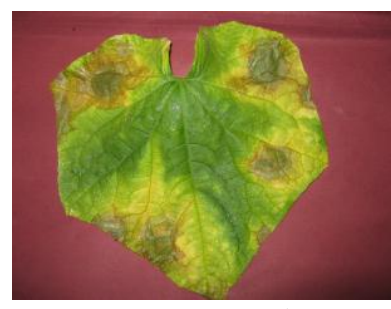

Control

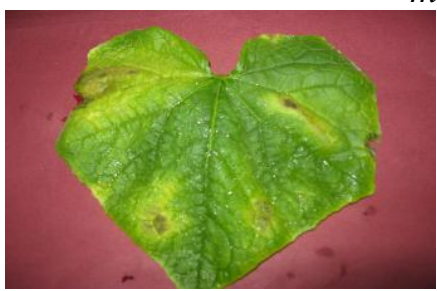

T. harzianum spray

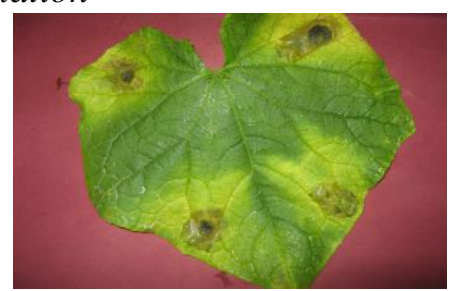

T. harzianum mixture inoculation

Fig. (6): Effect of different bioagents on cucumber leaf spot caused by Alternaria cucumerina

Bacillus spp. has been used to control a number of leaf spot diseases due to forming endospores facilitates long-term storage, relatively easy commercialization, capable of surviving desiccation, heat, oxidizing agents and $\mathrm{UV}$ and $\gamma$ radiation, as well as, produce a wide range of antibiotic compounds that are inhibitory to fungi (Bargabus et al., 2004). Antifungal factor includes siderophores, pterines, pyrroles (Sarani et al., 2008), phloroglucinols (Shanahan et al., 1992), proteases and chitinases (Nielsen et al., 1998). Bacteria produce antifungal antibiotics; elicit induced systemic resistance in the host plant (Aly, et al., 2002 and Atia et al., 2011).

Fayoum J. Agric. Res. \& Dev., Vol. 26, No.2, July, 2012 
REFERENCES

Alabouvette, C.; Y. Couteaudier; and J. Louvet (1984). Recherches sur la resistance des sols aux maladies. IX. Dynamique des populations du Fusarium spp. et de Fusarium oxysporum f. sp. melonis dans un sol resistant ou dans un sol sensible aux fusarioses vasculaires. Agronomie, 4: 735-740.

Aly, A. Z.; H. Buchenauer ; M.I. Abou-Zaid; M. Shalaby and M. M. Atia (2002). Induced resistance against tomato late blight disease by using biological agents. Egyptian J. Phytopathology, 30: 25-43.

Atia, M.M. (2005 a). Biological and chemical control of potato late blight. Annals of Agric. Sci. Moshtohor, 43 (4): 1401-1421.

Atia, M.M. (2005 b). Induction of resistance to alternaria leaf blight (Alternaria cucumerina) in melon by Dl- $\beta$-amino-n-butyric acid. J. Environmental Research, Zagazig Univ., Egypt, 6: 85-104.

Atia, M.M.; A.M. Esh and Shadia Taghian (2011). Efficiency of leaf surface fungal isolates in controlling cercospora leaf spot of sugar beet. Egyptian J. Appl. Science 26 (1): 13-37, Egypt.

Atia, M.M. ; Ahmed, Amal, M. (2011). Controlling of tomato early blight disease using some of biotic and a biotic agents. J. Plant Prot. and Pathology, Mansoura Univ., 2 (4): 481-500.

Atia, M.M. and A. M. Esh (2005). Role of biotic and a biotic agents on controlling alternaria fruit rots of tomato and pepper. Annals of Agric. Sci., Moshtohor, 43 (4): 1423-1440, Egypt.

Atia, M.M.; H. Buchenauer; A.Z. Aly and M.I. Abou-Zaid (2005). Antifungal activity of chitosan against Phytophthora infestans and actiation of defense mechanisms in tomato to late blight. J. Biological Agriculture and Horticulture, 23: 175-197.

Barnett, H.L. (1998). Illustrated genera of the imperfect fungi. Burgess Publishing Company, Minneapolis, Minn. USA, 218 pp., Fourth Ed

Batta, Y. (2003). Alternaria leaf spot disease on cucumber: susceptibility and control using leaf disk assay. An-Najah Univ., J. Research (N. Sc.), 17 (2): 269-279.

Batta, Y. (2005). Control of alternaria spot disease on loquat (Eriobotrya japonica Lind1.) Using detached fruits and leaf-disk assay. An-Najah Univ. J. Res. (N. Sc.), 19; 69-81.

Bargabus, R. L.; N.K. Zidack; J. W. Sherwood and B. J. Jacobson (2004). Screening for the identification of potential biological control agents that induce systemic acquired resistance in sugar beet. Biol. Control, 30: 342 350.

Chen, Z.; D.Q. Li; Y.F. Liu; Y.Z. Liu and C. Lou (2008). Screening of high yielding mutants of the bio control bacterium Bacillus subtilis bs-916 obtained by ion implantation, and the molecular mechanism of antagonistic ability. J. Plant Pathology, 90: 111.

Esh, A.M.; Atia, M.M and Taghian, Shadia (2010). Detection of systemic resistance in sugar beet elicited by non-pathogenic, phyllospherecolonizing Bacillus pumilus and B. subtilus against the pathogen Cercospora beticola saac. Egyptian J. Appl. Sci., 25 (8 B): 340-361.

Fawzi, E.M.; A.A. Khalil and A.F. Afifi (2009). Antifungal effect of some plant extracts on Alternaria alternate and Fusarium oxysporum. African J. of Biotecnology, 8(11): 2590 -2597.

Fayoum J. Agric. Res. \& Dev., Vol. 26, No.2, July, 2012 
EFFECT OF BIOTIC AND ABIOTIC AGENTS IN CONTROLLING.... 74

Gilardi, G.; D.C. Manker; M. Benuzzi; A. Garibaldi and M.L. Gullino (2008). Efficacy of Bacillus subtilis and Ampelomyces quisqualis alone and in combination with fungicides against Podosphaera xanthii of zucchini. J. Plant Pathology, 90: 268.

Hafez, Y.H. (2008). Effectiveness of the antifungal black seed oil against powder mildews of cucumber (Podosphaera xanthii) and barley (Blumeria graminis f. sp. hordei). Acta Biologica Szegediensis, 52(1):17-25.

Holt, J.G.; N. R. Krieg; P. H. Sneath; J.T. Staley; and S. T. Williams (1994). Bergey's Manual of Determinative Bacteriology $9^{\text {th }}$ ed. Williams and Wilkins Co. USA.

Latin, R.X. (1992). Modeling the relationship between alternaria leaf blight and yield loss in muskmelon. Plant Disease, 76; 1013-1017.

Latin, R.; K. K. Rane; and K. J. Evansm (1994). Effect of alternaria leaf blight on soluble sold content of muskmelon. Plant Disease, 78: 979-982.

Lawrence, C.B.; T.K. Mitchell; K.D. Craven; Y. Cho; R.C. Cramer and K.H. Kim (2008). At Death's Door: Alternaria pathogenicity mechanisms. Plant Pathology J., 24 (2): 101-111.

Leifert, C.; H.Li.; S. Chidburee ; S. Hampson; S. Workman; D. Sigee; H.A. Epton A. and A. Harbour (1995). Antibiotic production and biocontrol activity by Bacillus subtilis CL27 and Bacillus pumilus CL45. J. Appl. Bacteriol., 78:97-108.

Lorito, M. (1998). Chitinolytic enzymes and their genes. In: Kubicek, C P. ;Harman, G. E. (eds) Trichoderma and Gliocladium, vol 2. Taylor and Francis, London, pp 73-99.

Meena, P.D.; R.L. Meena; C. Chattopadhyay and A. Kumar (2004). Identification of critical stage for disease development and biocontrol of Alternaria blight of Indian Mustard (Brassica juncea). J. Phytopathology 152: 204-209.

Mesta, R.K.;V.I. Benagi; S. Kulkarni and I. Shankergoud (2009). In vitro evaluation of fungicides and plant extracts against Alternaria helianthi causing blight of sunflower. Karnataka J. Agric. Sci., 22(1): 111-114.

Mironescu, M. and C. Georgescu (2008). Preliminary researches on the effect of essential oils on moulds isolated from surfaces. Journal of Agro Alimentary Processes and Technologies; 30-33.

Parajuli, R.R.; R.D. Tiwari; R.P. Chaudhary and V.N. Gupta (2005). Fungi-toxicity of the essential oils of some aromatic plants against Alternaria Brassicicola. Scientific World, 3 (3): 39-43.

Parasada, R.; G.L. Khandelwel and P. Jain (1972). Epidemiology, forecasting and control of alternaria blight of cucurbits. Proc. Indian Nat. Sci. Acad, 37: 301-308.

SAS Institute Inc. (1999). Getting started with the ADX Interface for Design of Experiments, Cary, NC: SAS Institute Inc.

Sharvelle, E.G. (1961). The nature of uses of modern fungicides. Buryess Publ. Company Co., Minneapolis.

Singh, S.D. and B.S. Siradhana (1990). Laboratory evaluation of fungicides against Cephalosporium maydis causing late wilt of maize. Pesticides (1988), 22 (10): 33 - 34. (c. f. Indian Rev. Pl. Path.,1990, 69, (8): 606, 4928).

Sitara, U.; I. Niaz; J. Naseem and N. Sultana (2008). Antifungal effect of essential oils on in vitro growth of pathogenic fungi. Pak. J. Bot.; 40 (1): 409-414.

Fayoum J. Agric. Res. \& Dev., Vol. 26, No.2, July, 2012 
Atia M.M., et al.,

Snedecor, G.W. and W.G. Cochran (1980). Statistical methods. The Iowa State Univ., Press. Amer. USA, $7^{\text {th }}$ ed.

Suwitchayanon, P. and K. Kunasakdakul (2009). In vitro effects of clove and turmeric extracts controlling crucifer pathogens. Journal of Agricultural Technology, 5(1): 193-199.

Tegegne, G. and J.C. Pretorius (2007). In vitro and in vivo antifungal activity of crude extracts and powdered dry material from Ethiopian wild plants against economically important plant pathogens. Biocontrol, 52: 887-888.

Thomas, C.E. (1983). Fungicide applications based on duration of leaf wetness periods to control alternaria leaf blight of cantaloupe in South Texas. Plant Disease, 67;145-147.

Thomas, C.E.; J.D. McCreight and E.L. Jourdain (1990). Inheritance of resistance to Alternaria cucumerina in Cucumis melo line MR-1. Plant Disease, 74; 868- 870.

Vakalounakis, D. J. (1990). Alternaria alternata f. sp. cucurbitae, the cause of a new leaf spot disease of melon (Cucumis melo). Ann. App. Biol., 117: 507-513.

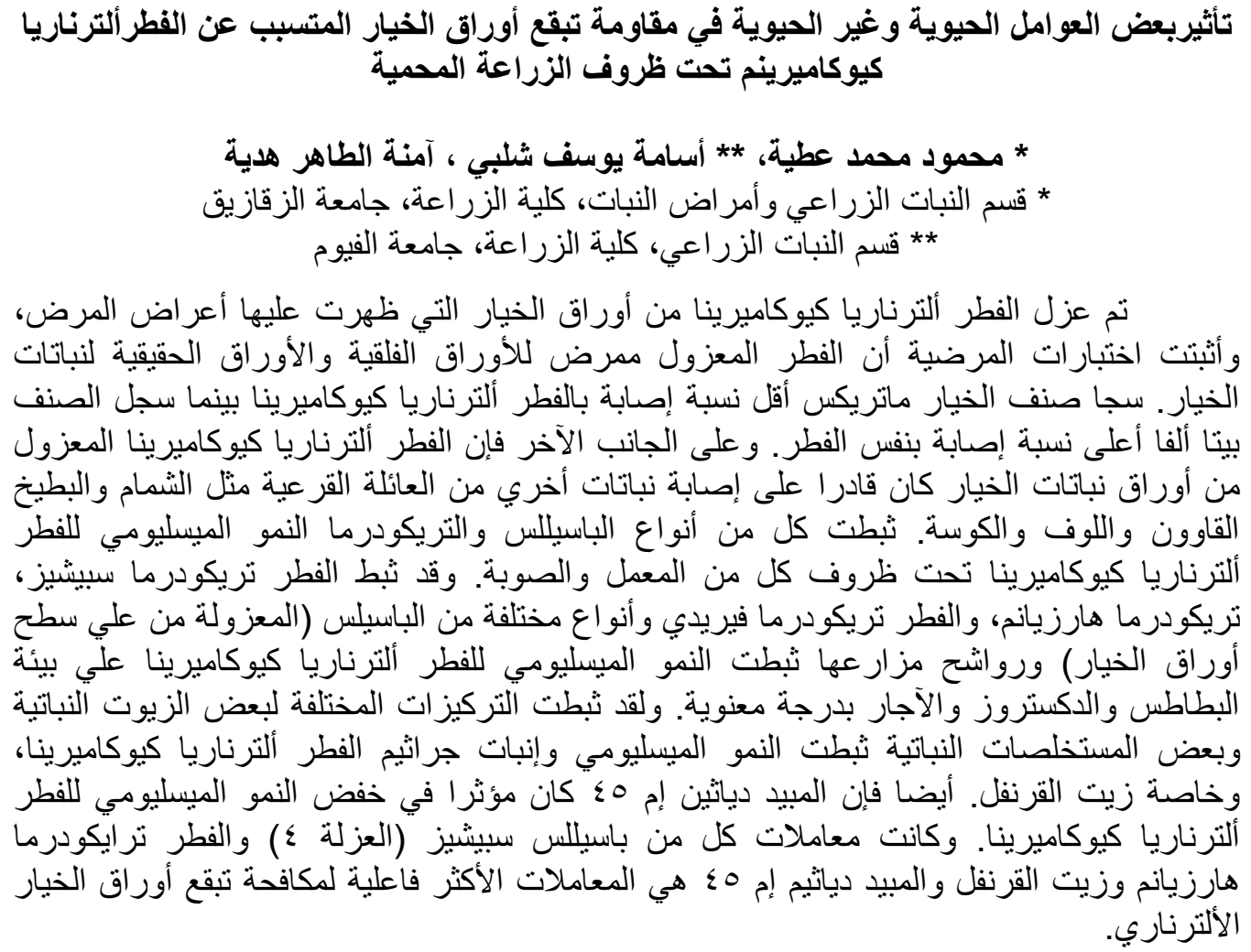

